\title{
CHANGE OF LIVING STANDARDS IN LITHUANIA, LATVIA ANDESTONIA AFTER JOINING THE EUROPEAN UNION
}

\author{
DAIVA VerKuleVIČIŪTÉ-KRIUKIENE $\dot{1}^{1}$
}

Klaipeda University (Lithuania)

\begin{abstract}
This article aims to compare the change of living standard in Lithuania, Latvia and Estonia after joining the European Union. The characteristics of living standard are analyzing before joining the EU and after 2004. It is also compared changes of living standard characteristics after the economic crisis. Indicators of living standard, such as the average monthly gross wages, consumer price index, purchasing power, unemployment rate, at-risk-of-poverty rate and others are calculated and compared. The three Baltic states are not only compared with each other, but are also analyzed in the context of the EU. Thus, it can be stated that among the three Baltic States, Estonia is distinguished by highest living standard. Although before the integration Lithuania was ahead of Latvia, but now Lithuania was lower than Latvia by particular characteristics of living standard.

KEY WORDS: living standard, Lithuania, Latvia, Estonia, European Union.
\end{abstract}

JEL CODES: I31, J31, J64, R13, R 23

DOI: http://dx.doi.org/10.15181/rfds.v14i3.875

\section{Introduction}

In 2004 Lithuania, Latvia and Estonia joined the European Union, and many new opportunities opened up for these nations. Membership of the EU has led the investment, economic growth, and living standards also had to grow up. What is the difference of living standard of these three countries? Which country is the best for living of population and which are faced with major challenges?

Problem. Among the three Baltic States, Estonia is distinguished by economic development. Estonia's transition process is internally seen a success story. Estonian transition choices have been quite specific, including a radical currency reform, fast privatisation and "shock therapy" during the pension reform. As a result, Estonia is in the top of most scoreboards of Baltic countries (Veebel at al., 2012: 181).

Lithuania and Latvia have also been rapid development, however, these two countries according to economic indicators are below Estonia. What is the difference in living standards between the three countries and in the EU context? This study did not aim to determine the EU's influence in the Baltic economies. These studies are carried out and this influence is undeniable.

All three countries have survived the economic crisis and its impact on the living standards is strong (Experiencing (...), 2012; Krusell, 2012; Maslauskaite at al., 2013; Gerstberger at al., 2013). Therefore, studies of living standard is also important to determine how quickly the country is recovering from the economic crisis. All of these issues led to formulate research purpose and objectives.

Research object - the standard of living.

1 Daiva Verkulevičiūtè-Kriukienė - doctor of geography sciences, lecturer, Faculty of Social Sciences, Klaipeda University. Scientific interests: social economic and territorial processe

E-mail: verkuleviciute.daiva@gmail.com 
The research purpose - to compare the living standard of population in Lithuania, Latvia and Estonia after joining the European Union.

Tasks of the study:

- To analyze the dynamics of characteristics of living standard between Lithuania, Latvia and Estonia after joining the EU.

- Identify the differences of characteristics of living standard between Lithuania, Latvia and Estonia in the EU context.

To compare actual living standards, the European Commission, International Monetary Fund, OECD and United Nations convert GDP per capita at purchasing power parities GDP per capita adjusted for purchasing power parities (PPP) as the indicator is used to determine the dfe of living standards between countries (Kammourieh, 2010: 3).

Gross national income per capita (GNI) and PPP Gross national income per capita measures are used for evaluate and compare the Living standard.

T. Tiusanen (2004) compare living standard in the three Baltic States with that in Scandinavia countries. Author state, that Denmark is almost nine times richer than Latvia with the lowest marking. Finland and Sweden are almost six times wealthier than Estonia. At the same time in 2002 price levels in the Baltic States was below $50 \%$ of the Euro area average price level (Tiusanen, 2004: 13, 15). Thus, the Baltic States before accession to the EU differed significantly from the old EU member states according to economic indicators.

Dealing with one dimension of time to separate the impact of the integration of the general structural change is very difficult. In order to accurately identify the impact of integration, panel data models is using. It was found, that the integration has been a significant on economic indicators during the period 2004-2006 of Lithuania and other countries which accessed to the EU in 2004 (LR Vyriausybès kanceliarijos (...), 2007: 69).

Methods. In order to implement the purpose and tasks of this research, data from the statistics authorities of Lithuania, Latvia and Estonia were used, which were systemized, grouped and analyzed. Pearson's correlation coefficient was calculated and the relationship between the various characteristics of living standard was determined. The comparative analysis is also used. To visually show the distribution of different values, a graphical method was applied.

\section{Macroeconomic changes after accession to the EU}

When Baltic countries joined the European Union, the possibilities opened up to European Union funding. Part of the funds associated with the improvement of living standards and conditions of living awarded by Quality Employment and Social Inclusion priority. For the period 2007-2013 from the EU funds (European Social Fund, the European Regional Development Fund and Cohesion Fund) the maximum amount of funds have been earmarked for Lithuania. EU funds for Latvia accounted for $66.3 \%$ and Estonia $-50.2 \%$ of the amount provided for in Lithuania (Fig. 1). Thus, the EU funding commensurate with the size of country and number of population. However, at the end of 2013, the interim payments of the European Union to Lithuania and Estonia was $67 \%$, while to Latvia - only $55.8 \%$. Lack of funding and uptake of funds affected the Baltic countries for further economic and social development.

Since 2004 the export flows increased to the EU. After accession to the EU, foreign direct investment (FDI) growth rates increased substantially during the first three years. FDI in Lithuania increased by more than two times prior to accession to the EU (2001-2003) (LR Vyriausybès kanceliarijos (...), 2007: 9-11).

Thus, since the join to EU, economic reforms and large-scale foreign direct investment, together with EU funds, led to grow economic development (Experiencing the economic (...), 2012: 3-4). 


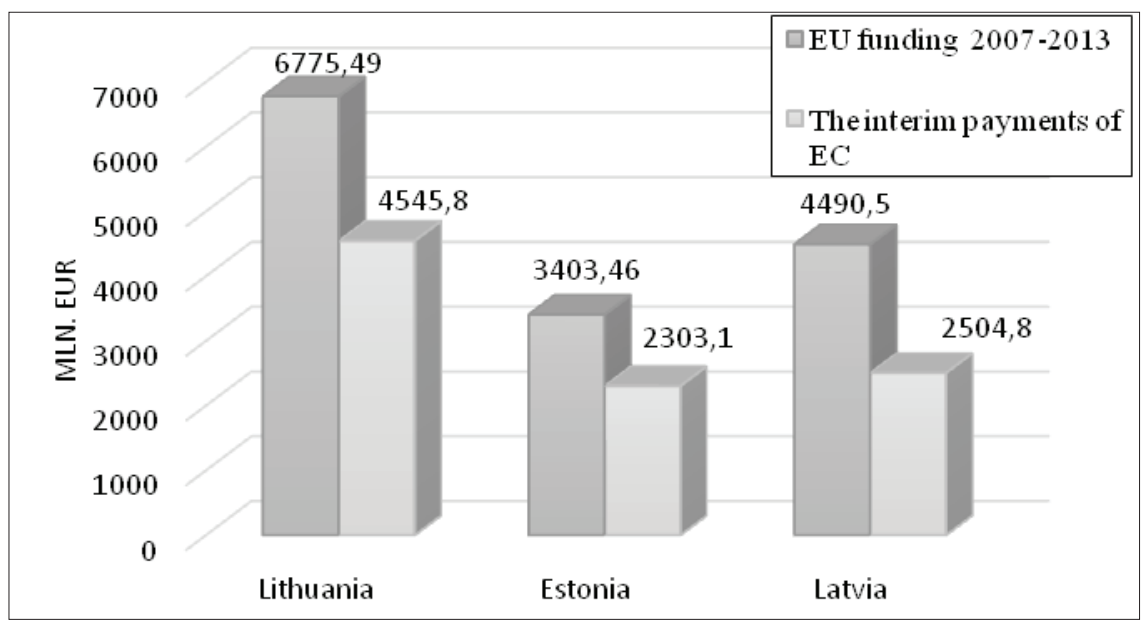

Fig. 1. EU funding and the interim payments of European Commission to 01-12-2013 in Lithuania, Latvia and Estonia (mln. EUR)

Source: ES struktūrinė parama, 2013

EU financial support had a significant direct and positive impact on GDP growth and changes in the structure of labor productivity. When the EU financial support as a proportion of GDP increased by one percentage point, the GDP growth increased in average about 1 percentage point in the eight new EU countries (LR Vyriausybės kanceliarijos (...), 2007: 69).

From the point of view of economic change, these three Baltic states was the best new members of EU - the high grow of GDP between 1995 and 2002 found in Latvia (42.6 \%), Estonia (40.5 \%) and Lithuania (31.9\%) (Tiusanen, 2004: 18).

Living standards in the New Member States of the European Union converged very rapidly towards the average European standard of living over the first decade of the new century. After accession to the EU economy is constantly growing. The beginning of the membership (2004) GDP per capita in Estonia, Latvia and Lithuania were accordingly $55 \%, 44 \%$ and $50 \%$ of the EU average. In 2007 economic growth in Latvia, Lithuania and Estonia was very high and these countries was between leaders together with Slovakia. But the financial crisis may have hampered the convergence process and in 2009 GDP shrank by more than $10 \%$ in Baltic countries (Estonia, Latvia and Lithuania) (Kammourieh, 2010: 1; Experiencing the economic (...), 2012: 3-4). Year from 2007 to 2010 marks the transition from economic prosperity to economic downturn and depression due to the crisis (Experiencing the economic (...), 2012: 6).

Nevertheless, in 2012 GDP per capita in Estonia and Lithuania have accounted for more than $70 \%$ of the EU average, but in Latvia it was lower - $64 \%$. GDP per capita in the Baltic countries increased by an average $46 \%$ in $2004-2013$.

Table 1. GDP per capita in Latvia and Lithuania in relation to the Estonia average (Estonia $=100)$ in 1995, 2004, 2008 and 2013, \%

\begin{tabular}{|l|c|c|c|c|}
\hline Countries & $\mathbf{1 9 9 5}$ & $\mathbf{2 0 0 4}$ & $\mathbf{2 0 0 8}$ & $\mathbf{2 0 1 3}$ \\
\hline Lithuania & 74.5 & 75.3 & 83.7 & 84.9 \\
\hline Latvia & 78.0 & 65.0 & 86.8 & 84.0 \\
\hline
\end{tabular}

Source: Eesti statistics, 2014; Latvijas statistika, 2014; Lietuvos statistikos departamentas, 2014

GDP per capita in Lithuania and Latvia in 2013 accounted for $84 \%$ of the Estonian average ( 1 table).

Of course, the gross domestic product still does not reflect the individual's standard of living. Therefore, the following indicators will be analyzed to describe the standard of living of Lithuanian, Latvian and Estonian people. 


\section{Comparison of individual indicators of living standard}

Economic growth determines the increase of labor income. Between GDP per capita and the average monthly gross wage established a strong direct correlation (Lithuania $R=0.92$, Estonia $R=0.88$ and Latvia $R=0.82$, as $p<0.05$ ).

It should be noted that wages and salaries have grown in the Baltic countries before accession to the EU. The monthly gross wage in Lithuania three years before the accession to the EU grew by an average of $3.4 \%$ a year, but from 2004 to 2006 the average growth rate was $11.8 \%$ (LR Vyriausybès kanceliarijos (...), 2007: 15). However the biggest problem was (especially in Latvia economy) labor shortage as a result of which wage growth outpaces the increase in productivity (Akule: 13).

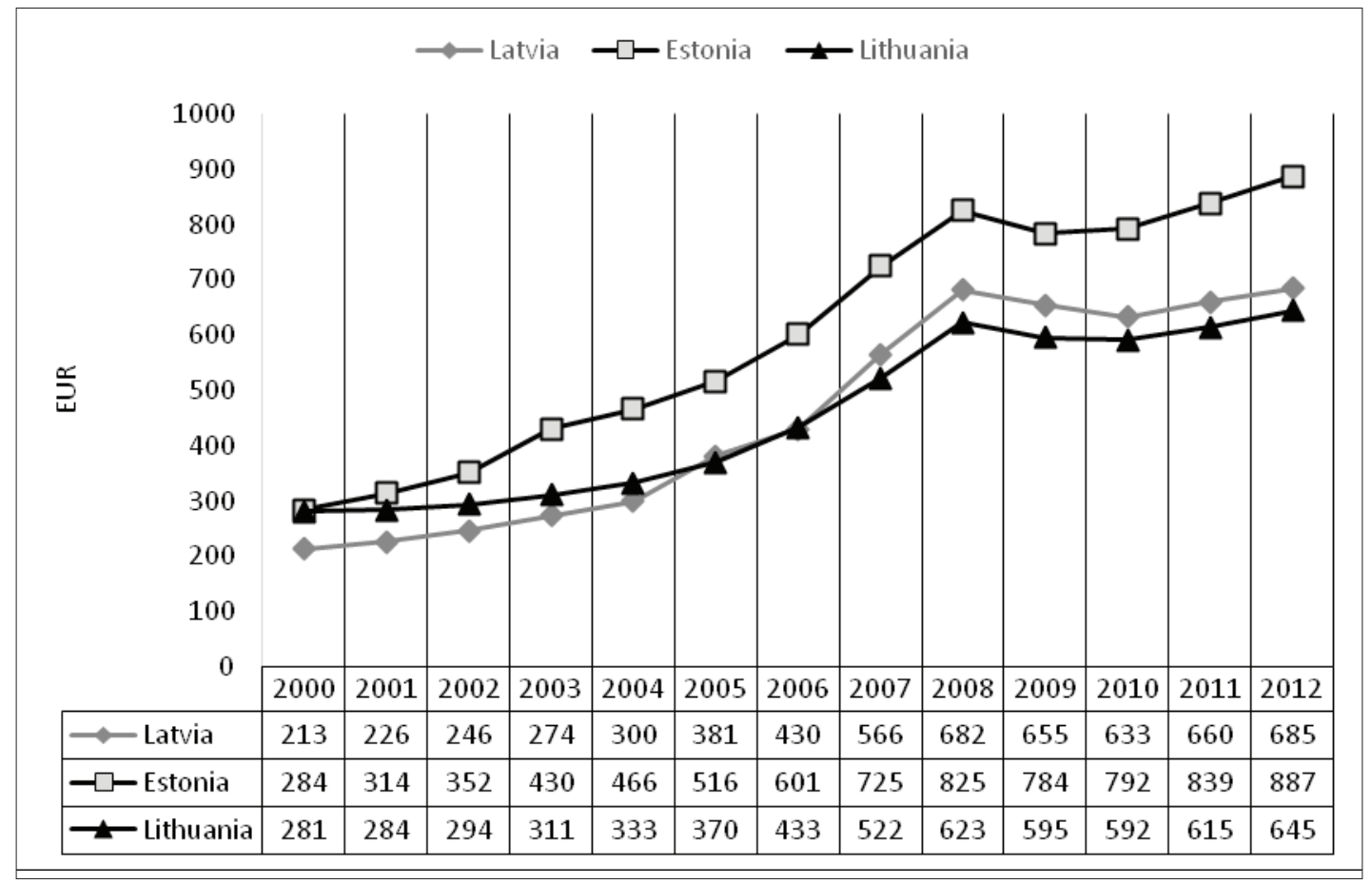

Fig. 2. Average of gross wages and salaries of the employed in Latvia, Estonia and Lithuania in 2000-2012, EUR

Sources: Eesti statistics, 2014; Latvijas statistika, 2014; Lietuvos statistikos departamentas, 2014

The average monthly gross wages and salaries in Estonia and Lithuania since the accession to the European Union increased by 51-52\%, in Latvia - $44 \%$. Now Estonia remains the leader, although in 2000 the wage in Lithuania was almost the same as in Estonia (Fig. 2). However, since 2006 wages and salaries in Latvia started to grow rapidly, and now Lithuania according to the monthly gross wage average remains in the last position in the Baltic States (72.7 \% of Estonian average).

When analysing the income sources, it is necessary to focus on the old-age pension, which is one of indicators of living standard of retirement age. Since 2009, residents of Lithuania received the lowest pensions among the Baltic States population. Average old-age pension in Lithuania is $27 \%$ lower than in Estonia and $8 \%$ lower than in Latvia.

Gini coefficient expresses the inequality in income distribution, which is also sometimes considered as index of living standard. In 2006 Latvia, Portugal, and Lithuania has the highest level of income inequality (Zaidi, 2009: 8). In 2010 the Lithuania has the highest income inequality among the Baltic States - Gini coefficient of equalized disposable income was 37 (Eurostat, 2014). Around one third of Lithuania population is at risk of poverty or social exclusion since they live in households with very low work intensity or are materially deprived. As the European Commission notes, the causes of such developments have not received the 
required policy attention (Masso, 2012: 12). However, in 2011 in Latvia Gini coefficient was already higher than in Lithuania and in 2012 between the three countries Lithuania has the lowest Gini coefficient (32) (Eurostat, 2014). Estonia has even established a strong negative correlation between the average monthly gross wages and the Gini coefficient $(R=-0.75)$, as $p<0.05$.

The income growth and the rise of prices affected the increasing of consumption expenditure. In 20042012 the household consumption expenditure grew by an average of $67.7 \%$ in all three countries. The largest increasing of consumption expenditure was on housing, water, electricity, gas, other fuels (120.1\%) and health services $(107.1 \%)$. This is a very important group of goods and services, and the opportunity to reduce the consumption to households is very low. As a result, people have less money to purchase the clothing and footwear or go to restaurants, cafes and hotels. In Lithuania consumption expenditure grew mainly on housing, water, electricity, gas and other fuels (144.8\%), furnishings, household equipment and routine household maintenance $(77.6 \%)$, miscellaneous goods and services $(85.0 \%)$ and education (73.9 \%). Meanwhile in Estonia consumption expenditure decreased on education (32.4\%), but has increased on recreation and culture (122.5\%). Among the three Baltic countries, consumption expenditure rose mostly in Latvia (73.7 \%). Compared to other countries, mainly in Latvia increased consumption expenditure on health (163\%), transport (105.5\%), food and non - alcoholic beverages (59 \%).

Since, according to the household consumption expenditure judged on the standard of living, it can be said that the highest standard of living is in Estonia - in 2012 one member of the household spent on average 284.6 EUR per month. Meanwhile, the lowest household consumption expenditure per capita in 2012 was in Lithuania - 247.3 EUR in Latvia - 282 EUR. Lithuanian households on average spend 5.6 \% more on food and non-alcoholic beverages, but $36 \%$ less on transport and $38.5 \%$ fewer on restaurants, cafes and hotels than Latvian households. These consumption rates do not reflect the differences between cities and villages. Urban residents may pay more money for various goods and services. The largest differences of consumption expenditure in Lithuania between urban and rural households was on housing, water, electricity, gas and other fuels $(77.2 \%)$, recreation and culture (88.5\%). Latvian urban population spend 2.2 times more than rural residents on restaurants, cafes and hotel. Consumption expenditure differences in Estonia between urban and rural households is lowest (average $8.2 \%$ ), but there are also urban residents spend more on housing, water, electricity, gas, other fuels and education (45\%).

Share of households having (great) difficulty making ends meet increased $4 \%$ in 2007-2010. Change of share of households having (great) difficulty making ends meet in Lithuania increased enormously - $15 \%$ in 2007-2010 period. This was the highest growth in the European Union. Some of these households in Latvia increased by $6 \%$, while in Estonia decreased even by $1 \%$ (Experiencing the economic (...), 2012: 7-8).

Consumer price index shows the average change in the price level of consumer goods and services purchased and used by households over a period of time to satisfy their needs. Starting with 2004 rise in prices is accelerating Lithuania (LR Vyriausybès kanceliarijos (...), 2007: 14).

In general consumer prices in all three countries has been growing, but at different levels. Growth of consumer prices in Lithuania and Estonia were similar (in 2012 increased to 139-140, where 2005 = 100), while consumer prices in Latvia grew faster, and in 2012 compared to 2005 increased by 147.9 (Eesti statistics, 2014; Latvijas statistika, 2014; Lietuvos statistikos departamentas, 2014).

It is very important for residents the change of consumer prices in Estonia and Latvia, when the euro was introduced. In Estonia, the euro was introduced on 1 January 2011. 2011 compared to 2010, the prices increased by $5 \%$, but in later years, the consumer price index declined - 2012 was $3.9 \%$, and in 2013 was $2.8 \%$. Latvia adopted the euro on 1 January 2013. In 2013 consumer prices over the previous year has been to 0. Consumer price index in Lithuania for several years has the downward trend. In 2012 the consumer price index was $2.8 \%$ over the previous year, and in 2013 it was only 0.4 .

After joining the European Union, prices of various goods and services increased in all Baltic countries. By 2012, consumer prices mostly increased by housing, water, electricity, gas, other fuels, recreation and tourism, and food compared to the index base period $(2005=100)$. This is not good, because costs of food 
and utilities account for a large share of total household spending. This reduces the availability of revenue for recreation, leisure, and other goods and services. At the same time communications costs in all countries declined. In Latvia prices increased for housing and utilities, food, hotels, restaurants and educational services.

The purchasing power of the residents at comparable prices is one of the main indicators of the standard of living, which shows the amount of goods and services can be purchased for revenues. Since joining the European Union, with increasing wages, the purchasing power of population has increased. However, the received wages of workers in Lithuania provided the opportunity to buy more milk, butter or Petrol A-95 than in other countries. In Latvia mostly increased purchasing power for the meat products. Unfortunately, the economic crisis reduced the purchasing power: wages and pensions decreased, but prices increased. As a result, in 2012, people were able to buy less Petrol A-95, sugar, bread and other products (Table 2).

Table 2. Change of purchasing power of employed by commodity in Lithuania and Latvia in 2005-2008 and 2008-2012

\begin{tabular}{|l|l|l|l|l|}
\hline \multirow{2}{*}{ Commodity } & \multicolumn{2}{c|}{ Lithuania } & \multicolumn{2}{c|}{ Latvia } \\
\cline { 2 - 5 } & $\mathbf{2 0 0 5}-\mathbf{2 0 0 8}$ & $\mathbf{2 0 0 8 - 2 0 1 2}$ & $\mathbf{2 0 0 5}-\mathbf{2 0 0 8}$ & $\mathbf{2 0 0 8 - 2 0 1 2}$ \\
\hline Sausage, boiled, kg & 21 & -6 & 54 & -6 \\
\hline Petrol A-95, liters & 246 & -232 & 176 & -141 \\
\hline Rye bread, kg & -23 & -60 & 1 & -44 \\
\hline Beef, kg & 3 & -3 & 40 & -27 \\
\hline Pork, kg & 21 & -2 & 48 & -7 \\
\hline Vodka plain, liters & 13 & -7 & 18 & -10 \\
\hline Milk, liters & 147 & -50 & 91 & -11 \\
\hline Sugar, kg & 204 & -119 & 207 & -64 \\
\hline Butter, kg & 31 & -21 & 5 & -13 \\
\hline
\end{tabular}

Source: Latvijas statistika, 2014; Lietuvos statistikos departamentas, 2014

The purchasing power of Estonian residents was $67 \%$ of the EU average in 2011, being significantly higher than in 2001 (46\%). Estonia is currently in the same group with countries like Hungary and Poland, with the Czech Republic not too far ahead. The purchasing power considerable increased in Latvia and Lithuania, but they are slightly behind Estonia (Krusell, 2012: 41).

Unemployment rate does not determine directly the standard of living, but rising of unemployment declining the availability of human labor income and improve their living standards. In this study, the unemployment rate is analyzed as an indirect indicator and the growth or decline of unemployment is analyzed in the context of the overall standard of living, as one of the factors.

We can distinguish three stages in the unemployment rate change in the Baltic countries. The first stage covers the period between 2004 and lasted until 2007, when the unemployment rate declined in all countries. Decreasing the number of unemployed suggests that the state needs to allocate less spending on social benefits. In 2007 the unemployment rate reached its lowest level in Lithuania and Estonia was from $4.2 \%$ to $4.6 \%$, while in Latvia was $6.2 \%$. A huge contraction in economic output in the Baltic countries and in Ireland caused serious problems in their labour markets. Since 2007, over three years due to the economic crisis, the unemployment rate increases of 12-13 percentage points and reach the maximum. In 2009-2010 the unemployment in Baltic countries was highest in EU (only in Spain unemployment rate was higher $20.1 \%$ ) (Experiencing the economic (...), 2012: 5). 


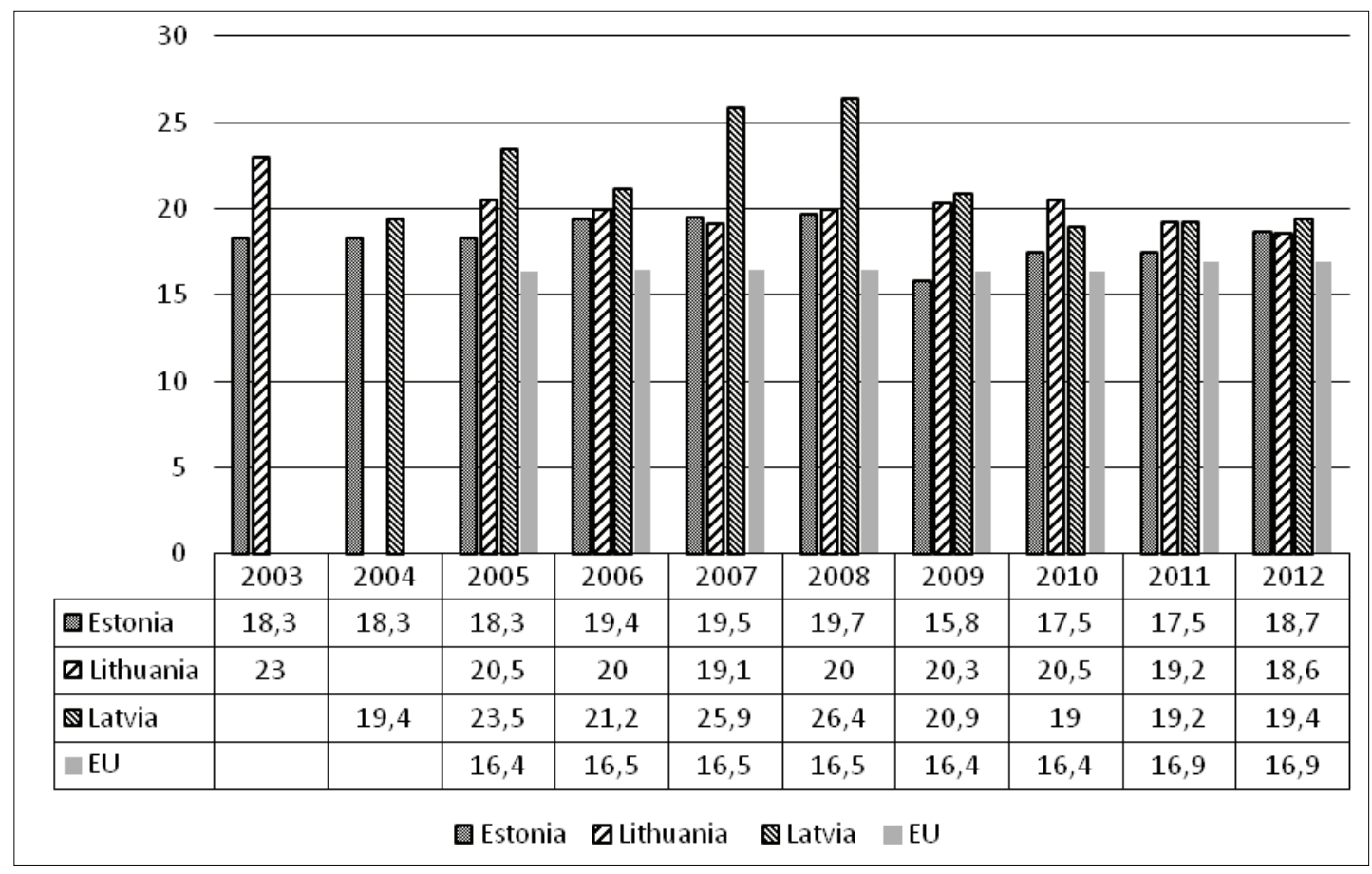

Fig. 3. At-risk-of-poverty rate in Estonia, Lithuania and Latvia in 2003-2012, \%

Sources: Eesti statistics, 2014; Latvijas statistika, 2014; Lietuvos statistikos departamentas, 2014

Unemployment rate in Latvia in 2010 even reached $19.8 \%$. Since 2010 the unemployment rate begins to fall, and the fastest falling observed in Estonia, and the slowest - Lithuania. In 2013 the unemployment rate in Lithuania and Latvia have become almost equal. Despite the low unemployment rate, the largest regional differences in 2013 was observed in Estonia - from 5.3 \% (Hiiu county) to 17.2 (Võru county).

Worse-than-expected developments on the labour market are undoubtedly one of the most important reasons of increasing poverty (Maslauskaite at al., 2013: 58). However, a strong negative correlation between unemployment rate and at-risk-of-poverty rate has established in Estonia and Latvia (accordingly $R=(-0.82)$ and $(-0.80)$, as $p<0.05)$. This means, that although the unemployment rate declined, the at-risk-of-poverty rate before the economic crisis remained high. Such correlation has not been established Lithuania.

Despite a growing economy and wages and salaries, in the Baltic countries at-risk-of-poverty rate remained almost unchanged, while in 2007-2008 even increased, especially in Latvia. In 2012 at-risk-ofpoverty rate in all three countries have tended to converge (Fig. 3). However, there are still large regional differences of at-risk-of-poverty rate. At-risk-of-poverty rate difference between the regions in Estonia (Tallinn exception) 18.7 percent point.

Social Climate Assessment (Special Eurobarometer (...), 2013) is associated with socio-economic phenomena analyzed in this study - variation of the unemployment rate and wages. In the Baltic States residents evaluate the social climate more negatively than positively, but Estonia's population believes, that the overall social climate assessment even better than the EU average (Fig. 4). Meanwhile, residents of Latvia and Lithuania in particular, evaluate the social climate negatively. Extremely badly social climate was assessed in 2010, when many of the socio-economic indicators also deteriorated sharply. Evaluations of social climate in 2011-2013 in all countries is improving. 


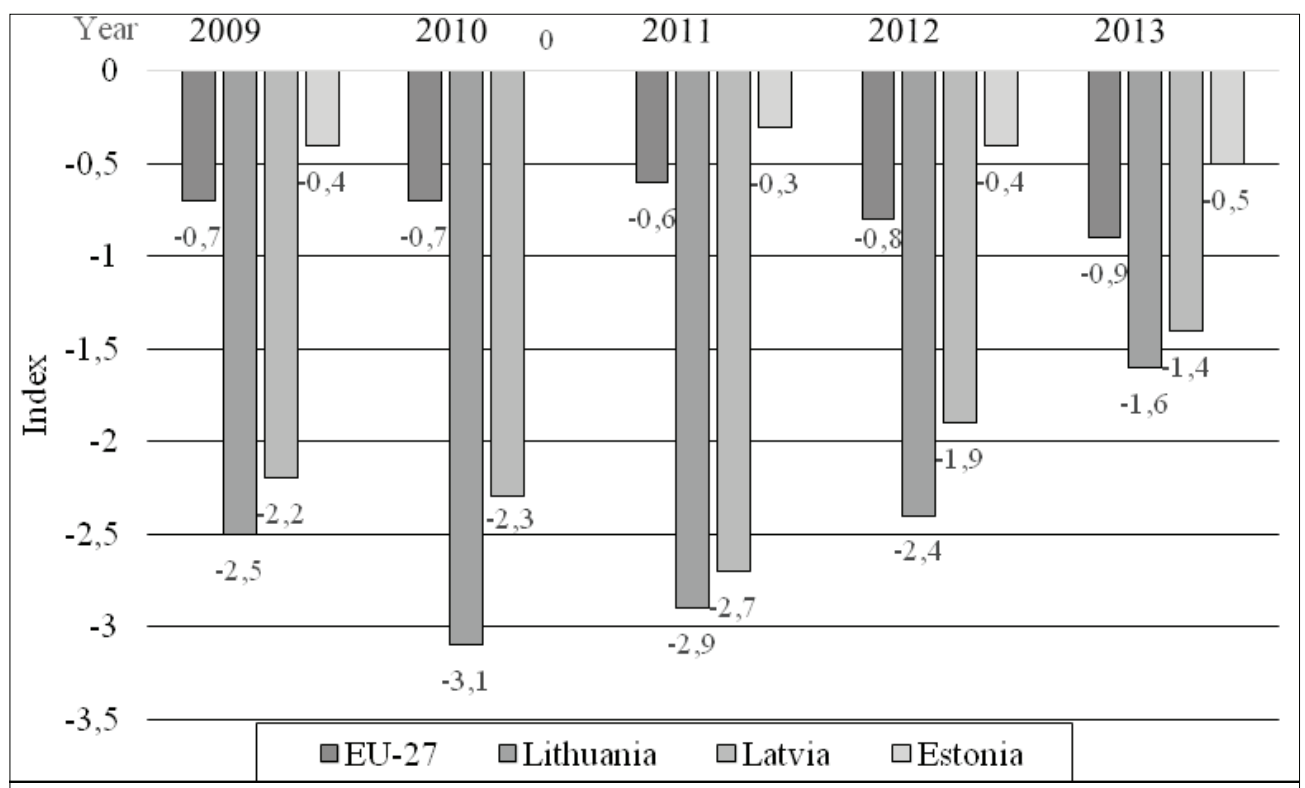

Fig. 4. The overall social climate index for the EU-27, Lithuania, Latvia and Estonia in 2009-2013 (evaluation of the current situation in scale from +10 to -10 )

Source: Special Eurobarometer, 2013: 10

\section{Conclusion}

Membership of the EU has led the investment, economic growth, and therefore the standard of living in the Baltic countries also grew.

GDP per capita in the Baltic countries increased by an average 46\% in 2004-2013. However, GDP per capita has grown rapidly in Estonia, while Lithuania GDP per capita growth was slower compared with Latvia, and now these two countries by GDP per capita almost equal. A similar trend occurred in the average monthly gross wage growth. In this time, workers of Lithuania get the lowest monthly gross wages $(72.7 \%$ of Estonian average) and pensioners of Lithuania receive lowest old-age pension.

Since, according to the household consumption expenditure judged on the standard of living, it can be said that the highest standard of living is in Estonia - in 2012 one member of the household spent on average 284.6 EUR per month. Meanwhile, the lowest household consumption expenditure per capita in 2012 was in Lithuania - 247.3 EUR in Latvia - 282 EUR.

Before the economic crisis the unemployment rate reached its lowest level in Lithuania and Estonia was from $4.2 \%$ to $4.6 \%$, while in Latvia was $6.2 \%$. Since 2007 , over three years due to the economic crisis, the unemployment rate increases of 12-13 percentage points and reach the maximum. Since 2010 the fastest falling of unemployment rate observed in Estonia, and the slowest - Lithuania. In 2013 the unemployment rate in Lithuania and Latvia have become almost equal.

Despite a growing economy and wages and salaries, in the Baltic countries at-risk-of-poverty rate remained almost unchanged, while in 2007-2008 even increased, especially in Latvia. In 2012 at-risk-ofpoverty rate in all three countries have tended to converge.

In the Baltic States residents evaluate the social climate more negatively than positively, but stands Estonia - Estonia's population believes, that the overall social climate assessment even better than the EU average. Meanwhile, residents of Latvia and Lithuania in particular, evaluate the social climate negatively. 
Thus, it can be stated that among the three Baltic States, Estonia is distinguished by highest living standard. Although before the integration Lithuania was ahead of Latvia, but now Lithuania was lower than Latvia by number of characteristics of living standard.

\section{References}

Akule, D. The Europeanization of Latvia: Becoming good Europeans? Policy documentation center. Website: http:// pdc.ceu.hu/archive/00004185/01/Akule_v1.pdf

Eesti statistika. (2014). GDP per capita in PPS. Website: http://www.stat.ee/29956

ES struktūrinè parama. (2013). LR Finansų ministerija. 2013 m. gruodžio 1 d. Europos Komisijos parengta lèšu panaudojimo statistika. Website: http://www.esparama.lt/ataskaitos/palyginimas-su-kitomis-es-salimis

Eurostat. (2014). At-risk-of-poverty rate by poverty threshold. Website: http://appsso.eurostat.ec.europa.eu/nui/show. do?dataset=ilc_li02\&lang=en

Experiencing the economic crisis in the EU: Changes in living standards, deprivation and trust. (2012). Eurofound. European Foundation for the Improvement of Living and Working Conditions, No. 7. Dublin. Website: http://www. eurofound.europa.eu/pubdocs/2012/07/en/1/EF1207EN.pdf

Gataūlinas, A., Zabarauskaitė, R. (2013). ES šalių subjektyvioji gerovė ekonominio išsivystymo ir socialinès politikos kontekste. Verslas: teorija ir praktika, Nr. 14 (2), p. 147-156. Vilnius.

Gerstberger, Ch., Yaneva, D. (2013). Analysis of EU-27 household final consumption expenditure - Baltic countries and Greece still suffering most from the economic and financial crisis. Eurostat. Economy and finance, No. 2. Website: http://epp.eurostat.ec.europa.eu/cache/ITY_OFFPUB/KS-SF-13-002/EN/KS-SF-13-002-EN.PDF

Kammourieh, S. (2010). Convergence and "deconvergence" of living standards in the New Member States of the European Union. Trésor - Economics, No. 82. Paris. Website: https://www.tresor.economie.gouv.fr/file/326916

Krusell, S. (2012). Standard of living labour market trends in Estonia - a comparison with other European Union countries during the recession. Elatustase ja tööturg. Standrad of living and labour market. Eesti Statistika Kvartalikiri, No. 4, p. 35-42. Tallinn. Website: http://www.stat.ee/dokumendid/67473

Latvijas statistika. (2014). Website: http://www.csb.gov.lv/

Lietuvos statistikos departamentas. (2014). Website: http://osp.stat.gov.lt/

LR Vyriausybes kanceliarijos Lietuvos integracijos i ES poveikio Lietuvos ekonomikai 2002-2006 metais (EX-POST) vertinimas. $2007 \mathrm{~m}$. gruodžio $17 \mathrm{~d}$. Galutinè tyrimo ataskaita. Vilnius. UAB „Ekonominės konsultacijos ir tyrimai““. Website: http://www.euro.lt/documents/poveikio_tyrimai/GALUTINE_ATASKAITA_ex_post_tyrimas.pdf

Maslauskaite, K., Zorgenfreija, L. (2013). Economic Miracle in the Baltic states: an exemplary way to growth? Part 2. The Baltic states in the EU: yesterday, today and tomorrow. Studies \& Reports, No. 98. Notre Europe. Jacques Delors Institute. Website: http://www.notre-europe.eu/media/balticstateseu-economicmiracle-maslauskaitezorgenfreija-ne-jdi-july13.pdf?pdf=ok

Masso, J., Espenberg, K., Masso, A., Mierina, I., Philips, K. (2012). GINI growing inequalities' impacts. Growing ineqalities and its impacts in the Baltics. Country Report for the Baltic States. Estonia, Latvia, Lithuania.

Quality of life in Europe: Subjective well-being. (2013). 3rd European Quality of Life Survey. European Commission. Luxembourg. Website: http://www.eurofound.europa.eu/pubdocs/2013/59/en/1/EF1359EN.pdf

Special Eurobarometer 408. Social Climate. (2013). Report. European Commission. Website: http://ec.europa.eu/public_opinion/archives/ebs/ebs_408_en.pdf

Tiusanen, T. (2004). The Baltic States - Successful Transition in Estonia, Latvia and Lithuania. Lappeenranta. Website: https://www.doria.fi/bitstream/handle/10024/31083/TMP.objres.346.pdf?sequence=1

Trapenciere, I. (2005). Poverty in Latvia. Fafo.

Veebel, V., Loik, R. (2012). Estonia: Life in Post-Communist Eastern Europe after EU Membership. Life in PostCommunist Europe after EU Membership. Ed. O'Beachain, D. Routledge: Taylor \& Francis Group, p. 163-184.

Zaidi, S. (2009). Main Drivers of Income Inequality in Central European and Baltic Countries Some Insights from Recent Household Survey Data. The World Bank. Europe and Central Asia Region. Poverty Reduction and Economic Management Department. Website: https://openknowledge.worldbank.org/bitstream/handle/10986/4016/ WPS4815.pdf?sequence $=1$ 


\title{
GYVENIMO LYGIO KAITA LIETUVOJE, LATVIJOJE IR ESTIJOJE, İTOJUS İ EUROPOS SĄJUNGĄ
}

\author{
DAIVA VerkUleVIČIŪTĖ-KRIUKIENĖ \\ Klaipėdos universitetas (Lietuva)
}

Santrauka

2004 m. Lietuvai, Latvijai ir Estijai ịstojus ị Europos Sajungą, šių valstybių gyventojams atsivèrè daug naujų galimybių. Narystė ES paskatino investicijas, ekonomikos augimą, todėl turejjo kilti ir gyvenimo lygis. ES finansinė parama darẻ reikšmingą tiesioginị ir teigiamą poveikị BVP augimui. Iš ES fondų 20072013 m. daugiausia lèšų numatyta skirti Lietuvai. ES fondų lèšos, skirtos Latvijai, sudare 66,3 \%, Estijai - 50,2 \% nuo Lietuvai numatytų lěšų sumos. Nepakankamas finansavimas, lěšų išnaudojimas ir finansavimo skirtumai turejjo įtakos valstybių ekonominei bei socialinei raidai.

İstojus ị Europos Sajungą, visose Baltijos valstybėse augo įvairių prekių ir paslaugų kainos. Iki $2012 \mathrm{~m}$. labiausiai išaugo būsto, poilsio ir turizmo, taip pat maisto produktų kainos. Tai nėra gerai, nes išlaidos maisto produktams ir komunalinèms paslaugoms sudaro didelę dalị visų namų išlaidų. Dėl to mažèja galimybių skirti pinigu poilsiui, laisvalaikiui, kitoms prekèms ir paslaugoms.

Vidutinis mėnesinis bruto darbo užmokestis Lietuvoje ir Estijoje nuo ịstojimo į Europos Sajungą išaugo daugiau kaip 51-52 \%, Latvijoje - $44 \%$. Nuo 2006 m. Latvijoje gyventojų darbo užmokestis pradèjo augti sparčiau ir dabar pagal vidutini mènesinį bruto darbo užmokestị Lietuva lieka paskutinè tarp Baltijos valstybių (72,7 \% Estijos vidurkio). Tarp Baltijos valstybių žemiausias pensijas gauna Lietuvos gyventojai. Lietuvoje senatvès pensijos dydis yra $27 \%$ mažesnis nei Estijoje ir $8 \%$ nei Latvijoje.

Nuo įstojimo ị Europos Sajungą, didėjant darbo užmokesčiui, augo gyventojų perkamoji galia. Už gautą darbo užmokestị pieno, sviesto ar benzino A-95 daugiau galima buvo ịsigyti Lietuvoje, tuo tarpu Latvijoje labiau išaugo perkamoji galia mėsos produktams. Deja, ekonominè krizė pakoregavo gyventojų perkamają galią: nors darbo užmokestis ir pensijos sumažèjo, kainos kilo. Dèl to gyventojų perkamoji galia taip pat sumažejo.

Kadangi pagal namų ūkių vartojimo išlaidų dydį sprendžiama apie gyvenimo lygị, galima teigti, kad aukščiausias gyvenimo lygis yra Estijoje: 2012 m. vienas namų ūkio narys vidutiniškai išleido 284,6 EUR per mėnesị. Žemiausios namų ūkių vartojimo išlaidos vienam nariui $2012 \mathrm{~m}$. buvo Lietuvoje - 247,3 EUR, Latvijoje - 282 EUR.

Baltijos valstybėse galima skirti tris nedarbo lygio kitimo etapus. Pirmasis apima laikotarpi nuo $2004 \mathrm{~m}$. iki 2007 m., kai visose valstybèse nedarbo lygis mažejo. Mažėjantis bedarbių skaičius rodo, kad valstybei mažiau išlaidų reikia skirti socialinėms pašalpoms. $2007 \mathrm{~m}$. nedarbo lygis pasiekè žemiausią ribą ir Lietuvoje bei Estijoje siekè 4,2-4,6 \%, tuo tarpu Latvijoje - 6,2 \%. Nuo $2007 \mathrm{~m}$. per trejus metus dèl ekonominès krizès nedarbo lygis išaugo 12-13 procentinių punktų ir pasiekè maksimumą. Latvijoje nedarbo lygis $2010 \mathrm{~m}$. pasiekè 19,8 \%. Nuo 2010 m. jis pradejo kristi, labiausiai tai pastebima Estijoje, léčiausiai krito Lietuvoje. 2013 m. nedarbo lygis Lietuvoje ir Latvijoje beveik susilygino.

Nepaisant augančios ekonomikos ir darbo užmokesčio dydžio, Baltijos valsybėse skurdo rizikos lygis beveik nepakito, o 2007-2008 m. netgi išaugo, ypač Latvijoje. $2012 \mathrm{~m}$. skurdo rizikos lygis visose trijose valstybèse beveik susilygino.

Socialinio klimato ịvertinimas siejamas su tyrime analizuojamais socialiniais ekonominiais reiškiniais nedarbo lygio ir darbo užmokesčio kitimu. Visų Baltijos valstybių gyventojai socialinį klimatą labiau vertina neigiamai, o ne teigiamai, tačiau čia išsiskiria Estija: jos gyventojų nuomone, bendras socialinio klimato vertinimas net geresnis nei ES vidurkis. Tuo tarpu Latvijos ir ypač Lietuvos gyventojai socialinị klimatą vertina labai žemu balu. Labai blogai socialinis klimatas vertintas $2010 \mathrm{~m}$., kai pablogejo daugelis socialinių ekonominių rodiklių. 2011-2013 m. socialinio klimato vertinimai visose valstybèse gerëja.

PAGRINDINIAI ŽODŽIAI: gyvenimo lygis, Lietuva, Latvija, Estija, Europos Sajunga. 